RADOVI

Zavoda za znanstveni rad HAZU Varaždin

EDUARD VARGOVIĆ

Varaždin

eduard.vargovic@vz.t-com.hr
UDK 001.814:929Kukuljević Sakcinski, I.(051)

Pregledni članak

Review

\title{
IVAN KUKULJEVIĆ SAKCINSKI U ČASOPISU RADOVI ZAVODA ZA ZNANSTVENI RAD HRVATSKE AKADEMIJE ZNANOSTI I UMJETNOSTI U VARAŽDINU
}

Tekst prikazuje istraživačke radove koji su o Ivanu Kukujeviću Sakcinskom objavljeni u ediciji Radovi Zavoda za znanstveni rad Hrvatske akademije znanosti i umjetnosti u Varaždinu.

\section{UVOD}

Zavod za znanstveni rad Hrvatske akademije u Varaždinu, koji je osnovan 1983. godine, obilježava 2016. godine trideset godina kontinuiranog izlaženja časopisa Radovi priznate Akademijine znanstvene edicije. ${ }^{1}$ Tri godine nakon osnivanja, 1986. Zavod pokreće časopis Radovi. ${ }^{2}$ Do 2015. godine tiskano je dvadeset i šest brojeva časopisa Radovi na gotovo sedam tisuća stranica s multidisciplinarnim tekstovima o Varaždinu i Sjeverozapadnoj Hrvatskoj. Više od dvjesto autora pripremilo je preko četiristo priloga u kojima su obrađena gotovo sva područja znanosti i umjetnosti.

Jedna od značajki časopisa, odnosno kontinuiranog djelovanja redakcije je tiskanje radova uz važne obljetnice događaja i pojedinih velikih i značajnih ljudi iz naše povijesti i sadašnjosti.

Ivan Kukuljević Sakcinski, veliko ime naše povijesti, također je zastupljen u tekstovima koji su objavljeni $\mathrm{u}$ časopisu Radovi, a predmet su naše analize. ${ }^{3}$

1 Zavod je utemeljen 24. lipnja 1983. potpisivanjem, u to vrijeme, važećeg Samoupravnog Sporazuma između tadašnje Jugoslavenske akademije i Općine Varaždin.

2 Prvi broj časopisa Radovi, tiskan 1986. god. predstavljen je javnosti 27. veljače 1987. u Gradskoj vijećnici u Varaždinu. Na predstavljanju su govorili: Petar Rihtarić, predsjednik Skupštine općine Varaždin i akademik Andre Mohorovičić, potpredsjednik JAZU i voditelj Zavoda.

3 Tekst je prezentiran na znanstvenom skupu Ivan Kukuljević Sakcinski (1816.-1889.), u povodu 200. godišnjice rođenja, Varaždin, 25. svibnja 2016. Organizatori: Hrvatska akademija znanosti i umjetnosti - Zavod za znanstveni rad u Varaždinu, Matica hrvatska, Ogranak u Varaždinu i Turistička zajednica Grada Varaždinske Toplice. 


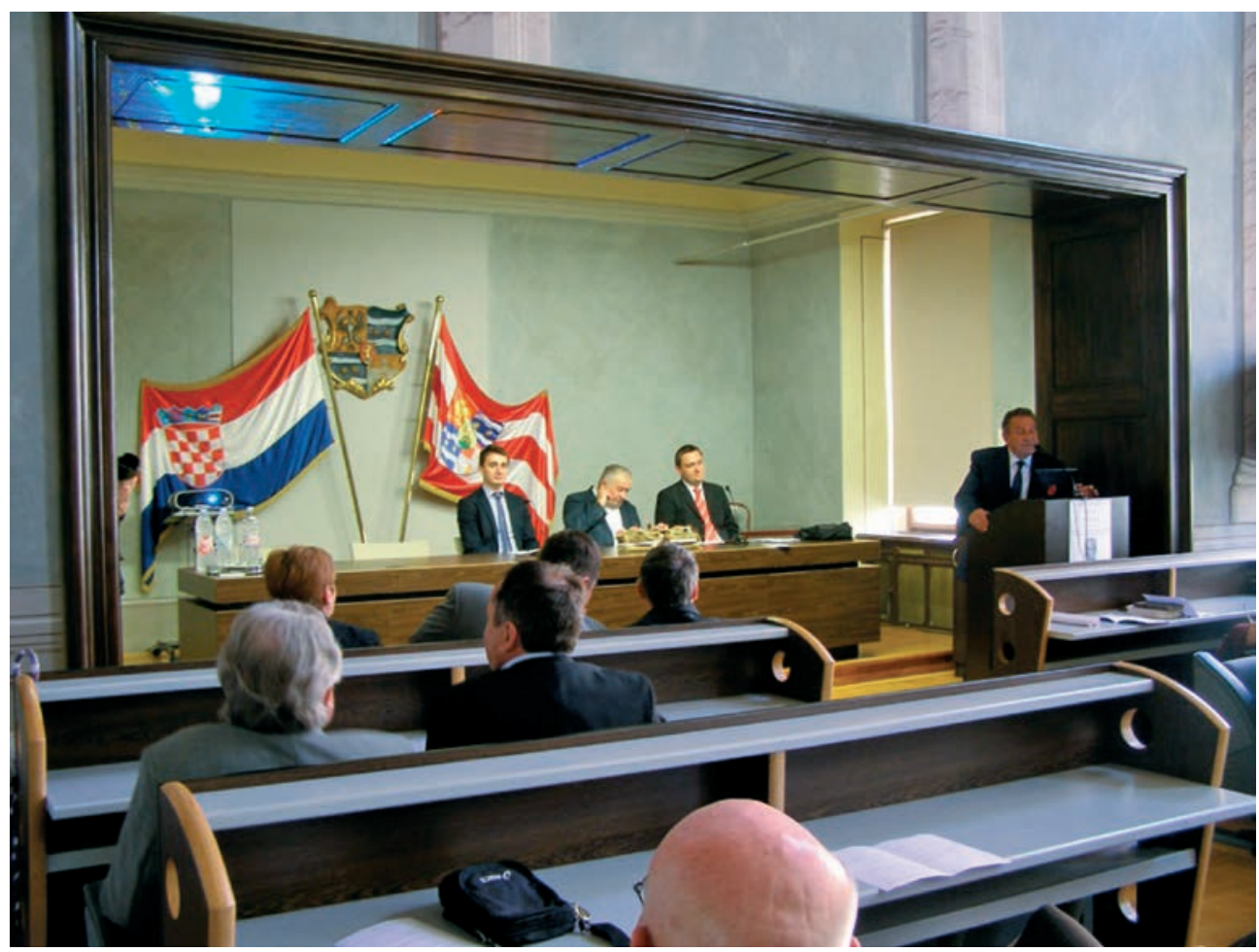

Slika 1. Znanstveni skup Ivan Kukuljević Sakcinski (1816-1889.), u povodu 200. godišnjice rođenja, Varaždin, 25. svibnja 2016.

\section{IVAN KUKULJEVIĆ SAKCINSKI U ČASOPISU RADOVI}

Tablica koju prilažemo, a koja će nam poslužiti za analizu, pokazuje prisutnost Ivana Kukuljevića Sakcinskog u pojedinim brojevima edicija Radovi: 
Eduard Vargović: Ivan Kukuljević Sakcinski u časopisu Radovi Zavoda za znanstveni rad HAZU u Varaždinu Radovi Zavoda za znanstveni rad HAZU Varaždin, br. 28, 2017., str. 117 - 135

Tablica 1. Radovi o Ivanu Kukuljeviću Sakcinskom - autori i teme

\begin{tabular}{|c|c|c|c|c|c|}
\hline $\begin{array}{c}\text { Redni } \\
\text { broj }\end{array}$ & Prezime /ime & Naslov rada & $\begin{array}{l}\text { Radovi } \\
\text { (broj/ } \\
\text { godina) }\end{array}$ & $\begin{array}{l}\text { Broj } \\
\text { stranica }\end{array}$ & Napomena \\
\hline 1. & Miroslav Kurelac & $\begin{array}{l}\text { Ivan Kukuljević Sakcinski - Život } \\
\text { i djelo }\end{array}$ & $\begin{array}{c}6-7 \\
1994 .\end{array}$ & $\begin{array}{c}101-116 \\
15\end{array}$ & $\begin{array}{l}\text { Izvorni znanstveni rad } \\
\text { „KD” 1993. }{ }^{1}\end{array}$ \\
\hline 2. & \begin{tabular}{|l|} 
Aleksandra \\
Kolarić
\end{tabular} & $\begin{array}{l}\text { Ivan Kukuljević i narodna } \\
\text { zahtijevanja 1848. godine }\end{array}$ & $\begin{array}{c}6-7 \\
1994 .\end{array}$ & $\begin{array}{c}117-121 \\
4\end{array}$ & $\begin{array}{l}\text { Izvorni znanstveni rad } \\
\text { „KD” } 1993 .\end{array}$ \\
\hline 3. & Ivan Zvonar & $\begin{array}{l}\text { Kukuljevićev odnos prema } \\
\text { usmenom narodnom } \\
\text { stvaralaštvu }\end{array}$ & $\begin{array}{c}8-9 \\
1996 .\end{array}$ & $\begin{array}{c}75-84 \\
9\end{array}$ & $\begin{array}{l}\text { Stručni rad } \\
\text { "KD" } 1995 .\end{array}$ \\
\hline 4. & $\begin{array}{l}\text { Mirjana Matijević- } \\
\text { Sokol }\end{array}$ & $\begin{array}{l}\text { Ivan Kukuljević Sakcinski kao } \\
\text { epigrafičar }\end{array}$ & $\begin{array}{c}8-9 \\
1996 .\end{array}$ & $\begin{array}{l}85-90 \\
5\end{array}$ & $\begin{array}{l}\text { Izvorni znanstveni rad } \\
\text { „KD” } 1994 .\end{array}$ \\
\hline 5. & Stjepan Hajduk & Ivan Kukuljević-povjesničar & $\begin{array}{l}10-11 \\
1998 .\end{array}$ & $\begin{array}{c}271-283 \\
12\end{array}$ & $\begin{array}{l}\text { Stručni rad } \\
\text { „KD“ } 1995 .\end{array}$ \\
\hline 6. & Miroslav Šicel & $\begin{array}{l}\text { Književnopovijesni rad Ivana } \\
\text { Kukuljevića Sakcinskog }\end{array}$ & $\begin{array}{l}10-11 \\
1998 .\end{array}$ & $\begin{array}{l}285-291 \\
6\end{array}$ & $\begin{array}{l}\text { Izvorni znanstveni rad } \\
\text { „KD“ } 1995 .\end{array}$ \\
\hline 7. & Ivan Zvonar & \begin{tabular}{|l} 
Motivsko-tematski svijet u \\
Kukuljevićevim zapisima \\
kajkavskih usmenih pjesama
\end{tabular} & $\begin{array}{l}10-11 \\
1998 .\end{array}$ & $\begin{array}{l}293-308 \\
15\end{array}$ & $\begin{array}{l}\text { Stručni rad } \\
\text { "KD" } 1995 .\end{array}$ \\
\hline 8. & Denis Peričić & $\begin{array}{l}\text { Korespondencija Ivana } \\
\text { Kukuljevića- s posebnim } \\
\text { osvrtom na korespondenciju } \\
\text { Kukuljevića i Franje Račkog }\end{array}$ & $\begin{array}{l}10-11 \\
1998 .\end{array}$ & $\begin{array}{c}309-313 \\
4\end{array}$ & $\begin{array}{l}\text { Izvorni znanstveni rad } \\
\text { „KD“ } 1995 .\end{array}$ \\
\hline 9. & Božena Filipan & $\begin{array}{l}\text { Značajke biografskih i } \\
\text { autobiografskih zapisa Ivana } \\
\text { Kukuljevića Sakcinskog }\end{array}$ & $\begin{array}{l}10-11 \\
1998 .\end{array}$ & $\begin{array}{l}315-331 \\
16\end{array}$ & $\begin{array}{l}\text { Pregledni rad } \\
\text { "KD“ } 1995 .\end{array}$ \\
\hline 10. & Božena Filipan & \begin{tabular}{|l|} 
Kukuljevićeva etnografska \\
istraživanja u Varaždinskoj \\
županiji i okolnim krajevima
\end{tabular} & $\begin{array}{l}12-13 \\
2001 .\end{array}$ & $\begin{array}{l}275-286 \\
\quad 11\end{array}$ & $\begin{array}{l}\text { Izvorni znanstveni rad } \\
\text { „KD“ } 1999 .\end{array}$ \\
\hline 11. & Tomislav Đurić & \begin{tabular}{|l|} 
Etnološko-folkloristički zapisi \\
Ivana Kukuljevića Sakcinskog u \\
«Danici Ilirskoj» (1842.-1846.)
\end{tabular} & $\begin{array}{l}12-13 \\
2001 .\end{array}$ & $\begin{array}{l}287-292 \\
5\end{array}$ & $\begin{array}{l}\text { Stručni rad } \\
\text { „KD“ } 1999 .\end{array}$ \\
\hline 12. & $\begin{array}{l}\text { Dubravka } \\
\text { Franković }\end{array}$ & $\begin{array}{l}\text { O glazbi i glazbenicima u } \\
\text { leksikografskom radu Ivana } \\
\text { Kukuljevića Sakcinskog }\end{array}$ & $\begin{array}{l}16-17 \\
2006 .\end{array}$ & $\begin{array}{c}153-161 \\
8\end{array}$ & $\begin{array}{l}\text { Pregledni rad } \\
\text { "KD" } 2001 .\end{array}$ \\
\hline 13. & $\begin{array}{l}\text { Stjepan } \\
\text { Damjanović }\end{array}$ & $\begin{array}{l}\text { Vatroslav Jagić o Ivanu } \\
\text { Kukuljeviću Sakcinskom }\end{array}$ & $\begin{array}{c}25 \\
2014 .\end{array}$ & $\begin{array}{l}107-113 \\
6\end{array}$ & $\begin{array}{l}\text { Pregledni rad } \\
\text { Okrugli stol o } \\
\text { Vatroslavu } \\
\text { Jagiću, Varaždin } \\
\text { 2013.2. }\end{array}$ \\
\hline & $\begin{array}{l}13 \text { priloga/11 } \\
\text { autora }\end{array}$ & & $\begin{array}{l}6 \text { brojeva } \\
\text { časopisa }\end{array}$ & 126 strana & \\
\hline
\end{tabular}

4 KD: Godišnja manifestacija „Kukuljevićevi dani“ u Varaždinskim Toplicama.

5 Hommage Vatroslavu Jagiću 1838. - 2013. Okrugli stol održan u Varaždinu 23. rujna 2013. godine. 
Ukupno je objavljeno 13 radova na 126 stranica. Jedanaest autora obradilo je sljedeće teme:

- Biografija Ivana Kukuljevića Sakcinskog (život i djelo)

- Povijest-politika

- Usmeno narodno stvaralaštvo / Kajkavska usmena književnost

- Kukuljević kao epigrafičar

- Kukuljević kao povjesničar

- Kukuljevićev književnopovijesni rad

- Kukuljevićeva korespondencija (F. Rački)

- Autobiografski i biografski zapisi Ivana Kukuljevića

- Kukuljević i etnografija / etnologija

- Kukuljević i glazba

- Vatroslav Jagić o Kukuljeviću.

Objavljeni tekstovi, osim jednoga, autorizirana su izlaganja na manifestaciji „Kukuljevićevi dani“ u Varaždinskim Toplicama u razdoblju od 1993. do 2001. godine. ${ }^{6}$ To su znanstveni skupovi koji su bili u organizaciji Zavoda Hrvatske akademije u Varaždinu, Matice hrvatske-ogranka u Varaždinskim Toplicama i Grada Varaždinske Toplice. Naravno, skupovi su održavali i kasnije, ali tekstovi o kojima ovdje govorimo vezani su za spomenuto razdoblje.

$\mathrm{U}$ tom periodu, svake godine održan je po jedan skup s temama vezanim za Ivana Kukuljevića Sakcinskog. Na godišnje skupove prijavilo se, prema dokumentaciji Zavoda, 42 sudionika. Međutim, kad je riječ o Ivanu Kukuljeviću Sakcinskom, nisu svi koji su na skupovima izlagali o Kukuljeviću poslali tekstove za časopis, već su samo čitali svoje radove i sudjelovali u raspravama. Dio prijavljenih sudionika nije došao na skup iz, najčešće, objektivnih razloga. Vidljivo je da je tek manji dio autorizirao svoje radove koji su onda, nakon recenzija, i objavljeni.

Dakako, to je prava šteta jer na skupovima „Kukuljevićevi dani“ u Varaždinskim Toplicama sudjelovalo je, kao što smo spomenuli, veliki broj istraživača s brojnim temama.

Prema dokumentaciji riječ je o pravom bogatstvu ideja i broja istraživača. To izgleda ovako:

6 Stjepan Damjanović, „Vatroslav Jagić o Ivanu Kukuljeviću Sakcinskom“, Hommage Vatroslavu Jagiću 1838. - 2013. Okrugli stol održan u Varaždinu 23. rujna 2013. godine. 


\section{TEME ZNANSTVENIH SKUPOVA NA ,KUKULJEVIĆEVIM DANIMA" U VARAŽDINSKIM TOPLICAMA}

\section{Arheologija}

1. Pregled rezultata dosadašnjih istraživanja i konzervatorskih zahvata na području Varaždinske županije

2. Antičko nasljeđe Ludbrega

3. Prijedlog sanacije i prezentacije antičke arhitekture u parku Var. Toplice

4. Rezultati dosadašnjih arheoloških istraživanja antičkog lokaliteta u Var. Toplice

5. Planovi i projekti zaštite arheoloških nalazišta u Varaždinskim Toplicama.

\section{Povijest - politika}

1. Kukuljevićeva povijest Medvedgrada

2. Prilike u Hrvatskoj u vrijeme djelovanja I. Kukuljevića Sakcinskog

3. I. Kukuljević Sakcinski i zbivanja 1848. u Hrvatskoj

4. Saborska odluka o uvođenju hrvatskog jezika u politički i javni život Hrvatske

5. Kukuljević i Saborska odluka o uvođenju hrvatskog jezika u politički i javni život Hrvatske.

6. Rimski vodovod u funkciji razvoja kupališta u Varaždinskim Toplicama

7. Arhivistička obrada obiteljskog fonda Kukuljević i mogućnosti novih povijesnih spoznaja

8. Kukuljević u vremenu i prostoru

9. Kukuljević povjesničar

10. Varaždinske Toplice u prostoru povijesnih zbivanja

11. Ivan Kukuljević - život i djelo

12. Varaždin u djelima Ivana Kukuljević Sakcinskog

13. Prikaz arhivske građe I. Kukuljevića Sakcinskog.

\section{Kultura}

1. Ivan Kukuljević Sakcinski i hrvatska tradicijska baština

2. Etnografsko istraživanje u Varaždinskim Toplicama i susjednim županijama

3. Arhiv za povijesnicu jugoslavensku kao izvor etnoloških istraživanja

4. Etnološko-folkloristički zapisi I. Kukuljevića Sakcinskog u Danici Ilirskoj 1841.-1846.

5. Kukuljevićeve zbirke narodnih pjesama

6. Utjecaj usmene književnosti na Kukuljevićevo književno stvaralaštvo 
7. Počeci hrvatskog jezika na sveučilištu

8. Doprinos Vrhovčeva kruga obrani hrvatskog jezika

9. I. Kukuljević Sakcinski u zaštiti kulturne baštine Hrvatske

10. I. Kukuljević Sakcinski i zaštita spomenika u Slavoniji

11. Kukuljević - novelist

12. Kukuljević - pjesnik

13. Kukuljević kao povjesničar književnosti

14. Kukuljević - dramatičar

15. Kukuljević - putopisac

16. Jačke gradiščanskih Hrvata u Kukuljevićevoj zbirci

17. Kukuljević- etnograf

18. Motivsko-tematski svijet u Kukuljevićevim zapisima kajkavskih usmenih pjesama

19. Značajke Kukuljevićevih biografskih radova i antibiografskih zapisa

20. Kukuljevićeva korespondencija s Franjom Račkim

21. Kukuljevićev prilog zaštiti pokretnih spomenika kulture

22. Kukuljevićev - epigraf

23. Kulturno povijesni spomenik u zapisima i opisima I. Kukuljevića - Sakcinskog

24. Kukuljevićev odnos prema usmenom narodnom stravaralaštvu

25. Ostavština I. Kukuljevića Sakcinskog iz fundusa Gradskog muzeja Varaždin

26. Kukuljević i njegove veze s Istrom, posebno s Petrom Kandlerom

27. Tonimir - obitavalište I. Kukuljevića Sakcinskog

28. Pisma I. Kukuljevića S. Vatroslavu Jagiću i Miklaušiću.

\section{Znanost}

1. Kukuljevićeve znanstvene inicijative.

\section{Školstvo}

1. Uloga Antuna Kukuljevića kao vrhovnog ravnatelja škola u Hrvatskoj

2. Uloga I. Kukuljevića Sakcinskog u hrvatskom narodnom preporodu i razvoju hrvatskog školstva

3. Članovi obitelji Kukuljević i nastava povijesti na zagrebačkoj Akademiji

4. Promišljanja odgoja u Kukuljevićevo doba

5. Spomen - škola Antuna i Ivana Kukuljevića u Varaždinskim Toplicama kao pilot škola za XXI. st. - dosezi i mogućnosti

6. Visokoškolstvo Varaždina i uvjeti njegova razvoja

7. Mjesto učiteljstva u kulturi hrvatskog naroda. 


\section{Putopisi}

1. Kukuljevićev put po Dalmaciji

2. I. Kukuljević Sakcinski u Dubrovniku

3. Iz dnevnika s puta po Italiji 1856. I. Kukuljevića Sakcinskog.

Ukupno 58 tema.

\section{Autori koji su prijavili teme}

K tome pridodajem imena autora koji su prezentirali svoje radove (odnose se na teme o I. Kukuljeviću Sakcinskom:

1. Miroslav Kurelac

2. Stjepan Hajduk

3. Miroslav Šicel

4. Matko Peić

5. Ljerka Šimunić

6. Ljerka Albus

7. Ivan Zvonar

8. Ivan Frangeš

9. Ernest Fišer

10. Denis Peričić

11. Bosiljka Paska

12. Vid Lončarić

13. Marina Šimek

14. Branka Vikić-Belančić

15. Dorica Nemeth

16. Božena Filipan

17. Josip Kolanović

18. Dubravka Franković

19. Stjepan Damjanović

20. Damir Hrelja

21. Tomislav Đurić
22. Milan Moguš

23. Josip Vončina

24. Dalibor Brozović

25. Ljubica Radović

26. Magdalena Lončarić

27. Agneza Szabo

28. Franjo Ruža

29. Mirko Marković

30. Zorica Petrić

31. Vesna Rapo

32. Višnja Zgaga

33. Slavica Stojan

34. Ljiljana Marks

35. Bruna Kuntić-Makvić

36. Zvonimir Bartolić

37. Ivan Čehok

38. Ennio Stipčević

39. M. Bertoša

40. Alojz Jembrih

41. Spomenka Težak

42. Mijo Korade

Ova dva popisa jasno pokazuju da je prava šteta da neki autori nisu poslali svoje radove. Ali to je inače problem znanstvenih skupova: istraživači pripreme izlaganja, sudjeluju u raspravama, ali ne pripreme svoje radove za objavljivanje.

To je voditelja Zavoda akademika Andru Mohorovičića, njegovog zamjenika prof. dr. sc. Slobodana Kaštelu i sve nas u neposrednom radu u Zavodu ponukalo 
da u pripremama velikih znanstvenih skupova u isto vrijeme pripremamo i tiskamo zbornike. Tako su u djelovanju našeg Zavoda nastali veliki znanstvenoistraživački i nakladnički projekti: Tako su, uz velike projekte, tiskani zbornici primjerice: Tržišna demokracija u Hrvatskoj - stanje i perspektive (2000.); Stvaralački potencijali u funkciji društveno-ekonomskog i kulturnog razvoja sjeverozapadne Hrvatske (2002.); 300 godina uršulinki u Varaždinu (2003.); Prometna povezanost Hrvatske s europskim zemljama u funkciji društveno-ekonomskog i kulturnog razvoja sjeverozapadne Hrvatske (2005.); Adolf Jurinac i njegovo djelo (2004.); Franjo Košćec i njegovo djelo (2008.); 800 godina slobodnog kraljevskog grada Varaždina, 1209. - 2009. (2009.); Varaždin i sjeverozapadna Hrvatska u Velikom ratu 1914. - 1918. (2014.).

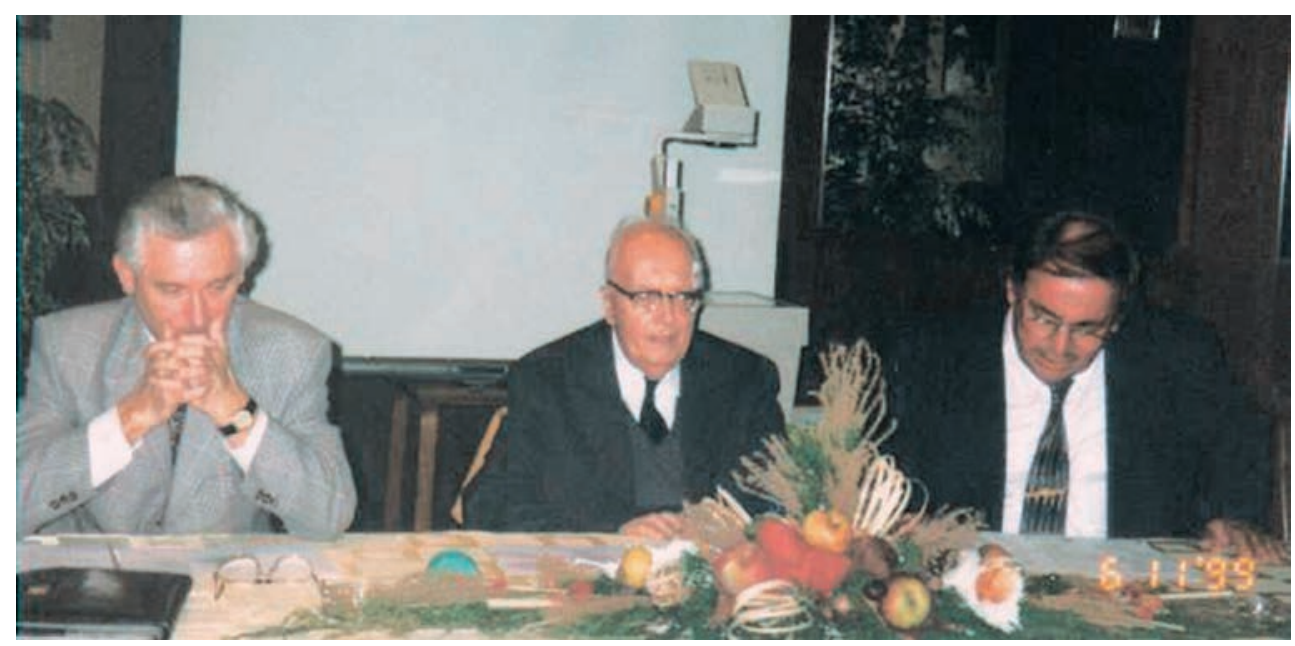

Slika 2. Voditelji skupa na Kukuljevićevim danima 1999.: Eduard Vargović, akademik Andre Mohorovičić, Anđelko Potrebica (gradonačelnik Grada Varaždinske Toplice).

\section{AUTORI O IVANU KUKULJEVIĆU SAKCINSKOM - PREGLED GLAVNIH MISLI ${ }^{7}$}

U sažetku svojeg rada Ivan Kukuljević Sakcinski - Život i djelo8 Miroslav Kurelac sažima nekoliko, po njemu, ključnih spoznaja o Kukuljeviću:

„Istaknuti hrvatski političar, znanstvenik - povjesničar i književnik, Ivan Kukuljević Sakcinski (rođen u Varaždinu 29. svibnja 1816., umro u Puhakovcu 1. kolovoza 1889. g.) bio je jedan od idejnih vođa hrvatskog narodnog preporoda,

\footnotetext{
Bilježimo ih kronološkim redom, kako su objavljivani u časopisu Radovi.
}

8 Radovi 6-7, 1994. 
javni djelatnik, utemeljitelj ne samo brojnih znanstvenih disciplina već i brojnih ustanova arhiva, knjižnica, muzeja, časopisa, kulturno-povijesnih društava. Bio je sakupljač povijesne građe, povijesnih izvora, (zemaljski arhiv), izdavač značajnih povijesnih dokumenata, pisac znanstvenih povijesnih rasprava, biograf, arheolog, povjesničar umjetnosti, bibliograf $\mathrm{i}$ bibliofil. Bio je sljedbenik i istomišljenik najprije Ljudevita Gaja, zatim Josipa Jurja Strossmayera, suradnik bana Josipa Jelačića i bana Ivana Mažuranića. Borio se i zalagao na raznim područjima javnog djelovanja na kulturnom, znanstvenom, političkom, pa i na vojnom polju za podizanje narodne svijesti, za samosvojnost i državnu samostalnost hrvatskog naroda. Kao političar istaknuo se rano sjajnim govorima u Varaždinskoj i Zagrebačkoj županiji, te napose u Hrvatskom saboru. Bio je član privremene hrvatske vlade tzv. Direktorija uoči 1848. g., član banskog vijeća za bana Josipa Jelačića, član banske konferencije i banski namjesnik 1865.-1867. g., te veliki župan zagrebačke županije. Bio je osnivač, tajnik i predsjednik „Društva za povjestnicu jugoslavensku“, i prvog povijesnog znanstvenog časopisa „Arkiv za povjestnicu jugoslavensku“, bio je načelnik i osnivatelj „Hrvatskog arkeologičkog društva“, podpredsjednik „Matice Ilirske“ i predsjednik "Matice hrvatske“, počasni član „Jugoslavenske akademije znanosti i umjetnosti“, te član mnogih uglednih znanstvenih udruženja i akademija. U doba apsolutizma A. Bacha i oktroiranog ustava povukao se iz političkog života i posvetio znanstvenom radu, pisanju i izdavanju brojnih znanstvenih, povijesni i književnih radova. Objavio je tako zbirku izvora "Monumneta historica Slavorum Meridionalium", I. Acta Croatica dokumente pisane hrvatskim jezikom glagoljiskim, ćirilskim i latinskim pismom; zbirku, kojom je želio dokazati hrvatska povijesna prava na samostalnost i državnost kroz vjekove.: "Jura Regni Croatiae Slavoniae et Dalmatiae“, I-III; te pojedinačne isprave u zbirci "Codex diplomaticus regni Croatiae, Slavoniae et Dalmatiae „I-III, (Zagreb, 1874, 1875.).

Objavio je i dragocjenu zbirku epigrafskih spomenika pod naslovom „Nadpisi sredovječnih i novovjeki na crkvah javnih i privatnih zgradah u Hrvatskoj i Slavoniji“, (Zagreb, 1891.).

Bilo da se radi o izdavanju izvora, kojima je Kukuljević želio „položiti temelj kritičkom obrađivanju povijesti“ ili povijesnim studijama, knjigama i raspravama, Kukuljević je dao temelje moderne historiografije u Hrvata u 19. stoljeću“. ${ }^{9}$

Drugi tekst iz našeg popisa je Aleksandre Kolarić: „Ivan Kukuljević i narodna zahtijevanja 1848. godine ${ }^{\prime 10}$ autorica konstatira ukratko: 
„Ulaskom Ivana Kukuljevića Sakcinskog na čelu grupe građana na sjednici gradskog magistrata grada Zagreba 17. ožujka u Hrvatskoj je započela politička akcija 1848.

Želeći ići zakonitim putem mogućnosti izbora bijahu im vrlo ograničene: Sabor nije bio zasjedao, namjesnik banske časti, biskup Juraj Haulik, nalazio se izvan zemje, vlast u zagrebačkoj županiji su od 1845. držali Mađari, pa se narodnjacima kao jedini legalni organ preko kojeg se mogla provesti politička akcija nametnuo gradski magistrat.

Tako na sjednici od 17. ožujka Kukuljević, kao jedini govornik, održao govor u kojemu je od kralja zatražen što brži saziv Sabora, kako bi i Hrvati „kako slobodni ljudi slobodnog naroda (...) starinskim i zakonitim putem dobili sve“ što je predlagano u Beču i Pešti“. ${ }^{11}$

U Radovima 8-9 nalazimo dva rada. Najprije zapisujemo rad Ivana Zvonara „Kukuljevićev odnos prema usmenom narodnom stvaralaštvu“. ${ }^{12}$ Pišući o Kukuljevićevim doprinosu istraživanjima i zapisivanja usmene književnost Zvonar argumentirano potvrđuje:

„Važno mjesto na prikupljanju primjera usmenog književnog stvaralaštva na hrvatskim prostorima pripada Ivanu Kukuljeviću Sakcinskom koji je prvi i tiskom objavio opsežnu zbirku narodnih pjesama na sva tri hrvatska narječja. Kukuljević je također prvi komentirao i pokušao riješiti poteškoće $s$ kojima se susretao pri bilježenju glasova za koje ne postoje odgovarajuća slova u grafemskom sustavu hrvatskoga književnog jezika.

Nakon Kukuljevićeva djela uslijedilo je tiskanje brojnih zbirki usmenih pjesama raznih melografa i folklorista.

Tiskana je građa do danas na adekvatan način proučena i ocijenjena.

Ostaju, međutim, još brojne pjesmarice iz različitih razdoblja koja tek čekaju i svoje proučavatelje i valorizatore ${ }^{13}{ }^{13}$

Drugi tekst iz istog broja pripada Mirjani Matijević-Sokol, „Ivan Kukuljević Sakcinski kao epigrafičar". U svom radu naročito naglašava slijedeće:

„Ivan Kukuljević Sakcinski u svojoj sveukupnoj i bogatoj djelatnosti na polju istraživanja i prikupljanja kulturne i povijesne baštine bavio se i epigrafikom. Otkrivao je, istraživao, obrađivao i publicirao epigrafičke spomenike od rimskih vremena do XIX stoljeća. Rad na epigrafičkoj baštini osmislio je i proveo kroz djelatnost „Društva za jugoslovensku povjestnicu i starine“. Svrha utemeljenja takvog

\footnotetext{
Radovi, 6-7, 1994. str. 117.

Radovi, 8-9, 1996.

Radovi, 8-9, 1996., str. 81.
} 
društva bila je sabiranje građe na temelju koje će se moći kritički pristupiti obradi povijesti hrvatskog naroda s ciljem osvješćivanja naroda.

Preko povjerenika, a osobitim trudom Mijata Sabljara, Kukuljević je dolazio do mnogih epigrafičkih spomenika. Objavljivao ih je u svojim izvješćima sa znanstvenih putovanja, u zbirkama diplomatičkih povijesnih vrela. Zaslužan je za otkrivanje u Veneciji krstionice kneza Višeslava i njezino pripisivanje hrvatskom kulturnom korpusu. Isto tako znanstvenicima je prvi ukazao na Bašćansku ploču i okušao se kao epigrafičar pokušavajući razriješiti taj izuzetno važan glagoljski natpis. Posthumno je objavljeno njegovo djelo „Nadpisi sredovječni i novovjeki na crkvah, javnih i privatnih sgradah itd. u Hrvatskoj i Slavoniji“ koje sadrži 1342 natpisa na latinskom, njemačkom i hrvatskom jeziku pisana latinicom, glagoljicom i ćirilicom. U Arhivu HAZU čuva se rukopis još jedne epigrafičke zbirke, koju je priredio za tisak, „Nadpisi istranski sa otoci Krkom, Cresom i Pagom“ s 573 natpisa, većinom iz Istre, ali i spomenutih otoka". ${ }^{14}$

Najviše priloga o Ivanu Kukuljeviću Sakcinskom tiskano je u Radovima broj 10-11 njih ukupno $5 .{ }^{15}$ Riječ je o vrlo interesantnim temama koje proširuju našu spoznaju o Kukuljeviću.

Stjepan Hajduk piše rad pod naslovom „Ivan Kukuljević - povjesničar“. ${ }^{16}$ Autor, također povjesničar, svoja razmišljanja formulira ovako:

„Ivan Kukuljević Sakcinski (1816. - 1889.) jedna je od najznamenitijih javnih osoba u Hrvatskoj u 19. st. Kao osnivač moderne hrvatske historiografije temeljito je obrađen u raspravi Jaroslava Šidaka.

Kukuljević je znanstvenik širokih interesa pa se zalagao za interdisciplinarni pristup povijesti, što se više odrazilo kod uvažavanja izvora koji nisu izrazito politički, nego u njegovim raspravama.

Ivan Kukuljević je objavio temeljne zbirke izvora za hrvatsku povijest, a hrvatskoj historiografiji dao je i prvu organizacijsku podlogu. Svojom radinošću i plodnošću ostao je nenadmašan" ${ }^{17}$

Drugi prilog iz spomenutog broja je tekst akademika Miroslava Šicela, „Književnopovijesni rad Ivana Kukuljevića Sakcinskog“. Naš ugledni povjesničar književnosti zapisuje:

„Ivan Kukuljević Sakcinski najviše prostora posvetio je, rekli bismo simbolički, trima povijesnim ličnostima: Katarini Zrinski, kao simbolu hrvatske žene, Petru

14 Radovi, 8-9, 1996., str. 88/89.

15 Radovi, 10-11, 1998. Časopis je posvećen 85. obljetnici života akademika Andre Mohorovičića, voditelja Akademijinog Zavoda u Varaždinu.

16 Radovi, 10-11, 1998.

17 Isto, str. 280-281. 
Zrinskom, simbolu hrvatskog otpora tuđincu i Jurju Križaniću u kome je vidio simbol sveslavenskog zajedništva; ali i Nikoli Zrinskom kao čovjeku koji je, u biti, zatajio svoj nacionalni identitet. Bio je to, zapravo, i Kukuljevićevo bitno shvaćanje političkog i duhovnog života hrvatske prošlosti, ali i ideja hrvatske budućnosti, sagrađene na iskustvu vlastite nacionalne povijesti.

Iako je tijekom svog dugog radnog vijeka napisao još tekstova koji, uz ostale probleme, dodiruju i pitanja hrvatske književnosti, kao - primjerice - u knjizi "Glasoviti Hrvati prošlih vijekova“ (1886.) u već poznim godinama kojoj donosi niz životopisa značajnih Hrvata pa tako i nekih književnika (Ivan Česmički, Juraj Habdelić, i drugi) - ipak tri analizirane knjige kao i priređivanje Marulićevih pjesama $\mathrm{u}$ „Starim piscima“ predstavljaju neprijeporno vrhunske domete Kukuljevićeve u hrvatskoj književnoj historiografiji“. ${ }^{18}$

Slijedeći tekst je autorski rad Ivana Zvonara „Motivsko-tematski svijet u Kukuljevićevim zapisima kajkavskih usmenih pjesama." Vrstan poznavatelj književnosti Zvonar dokumentirano bilježi:

„Kajkavske su se svjetovne narodne pjesme sporadično bilježile i prije Ivana Kukuljevića, ali bez ikakvih naznaka razvrstavanja po motivsko-tematskim cjelinama.

Tek je njegova opsežnija, prva u Hrvatskoj tiskana, zbirka „narodnih pesamah puka hárvatskoga" donijela građu koja je ponudila i veće mogućnosti za jednu motivskotematsku cjelinu.

Sam je Kukuljević, međutim, tek na kraju zbirke ponudio svega četiri tematska kruga, i to: "svatovne“, "romarske“, „kajkavske bajoslovne“, te „pesme ladarske“.

Slijedeći tragove nastanka pojedinih primjera iz spomenute zbirke, kasniji su zapisivači narodnih pjesama skupili građu za više opsežnih tematskih krugova, od kojih se na ovom mjestu mogu detaljnije opisati samo četiri: balade o razbojničkom vođi kojega je ubila njegova družina, romance o banu Lucipetru, nećaku kralja Matije Korvina, pjesme o tri udate sestre te pjesme o veselim mladim snahama.

Iz rečenog proizlazi da je tek s Kukuljevićem počela znanstvena klasifikacija kajkavskih narodnih pjesama, tako da su danas njegove zasluge i na tom području nezaobilazne ${ }^{\prime \prime}{ }^{19}$

Prilog iz spomenutog broja je i tekst Denisa Peričića: „Korespondencija Ivana Kukuljevića - s posebnim osvrtom na korespondenciju Kukuljevića i Franje Račkog“.

U svom vrlo dobrom prikazu Kukuljevićeve korespodencije Peričić naglašava:

\footnotetext{
8 Ibidem, str., 290.
}

19 Ibidem, str., 305. 
„Brojna Kukuljevićeva pisma suvremenicima, kao i njihovi odgovori Kukuljeviću, iscrpno nas izvješćuju o raznovrsnim djelatnostima svestranog kulturnog i političkog djelatnika. Jedna od najzanimljivijih prepiski koje je Kukuljević vodio zacijelo je dugotrajna prepiska s Franjom Račkim, povjesničarom i književnim povjesničarom, predsjednikom Jugoslavenske akademije znanosti i umjetnosti. Kukuljevićeva korespondencija, posebice njegova prepiska s Franjo Račkim, može svakako poslužiti kao valjan i koristan putokaz u istraživanjima ne samo Kukuljevićeva književnog djela, nego i sveukupnog života i opusa obaju pisaca, pa bi je u dogledno vrijeme trebalo (tiskom) u cijelosti objaviti““. ${ }^{20}$

Posljednji rad je tekst Božene Filipan koji piše: „Značajke biografskih i autobiografskih zapisa Ivana Kukuljevića Sakcinskog“. Držeći se svojih istraživanja argumentirano zaključuje, ali i predlaže:

Ivan Kukuljević Sakcinski utemeljio je suvremenu hrvatsku biografiju, i kao njen teoretičar i kao pisac biografskih monografija i biografskih zbornika. Znanstvenim raspravama pridonio je razvoju biografske i povijesti hrvatske književnosti, a biografskim leksikonom utemeljio je i povijest umjetnosti. U hrvatsku književnost uveo je usporedne literarni biografije nastojeći stvoriti "hrvatskog Plutarha". Njegove znanstvene postavke bliske su zahtjevima moderne biografije, a ostvario ih je prema znanstvenim spoznajama i mogućnostima svoga vremena.

Korisno bi bilo prirediti kritičko izdanje zbornika "Glasoviti Hrvati prošlih vjekova“.

Autobiografski i dnevnički zapisi su pouzdano, ali ne i jedini izvori za proučavanje osobnog, književnog i političkog razvoja Ivana Kukuljevića Sakcinskog. Mladenački dnevnici tek dopunjeni književnom ostavštinom i korespondencijom pokazuju kako je mladi Kukuljević već u 1835.-36. godini ostvario svoje hrvatske pjesme i prve dramske pokušaje: prva rukopisna zbirka s igrokazom „Beg Bele“ $\mathrm{i}$ pjesmama nastala je početkom 1836., a krajem iste godine i prva hrvatska verzija kasnije drame „Juraj i Sofija“ naslovljena tada „Boj kod Siska“.

Radi izrade kritičke biografije Ivana Kukuljevića Sakcinskog bilo bi potrebno da se hitno objedini njegova ostavština, koju bi onda trebalo svestrano proučiti i pojedine značajne njene dijelove, pogotovo korespondenciju, objaviti. ${ }^{21}$

Slijedeća dva priloga objavljeni su u Radovima broj 12-13.22 Božena Filipan piše: „Kukuljevićeva etnografska istraživanja u Varaždinskoj županiji i okolnim krajevima“. Naglašavajući važnost Kukuljevićevih etnografskih istraživanja Božena Filipan u svom sažetku zaključuje: „Autorica prikazuje Kukuljevićeva etnografska

\footnotetext{
Ibidem, str., 312 .

21 Ibidem, str., 328-329.

22 Radovi 12-13, 2001.
} 
istraživanja na području Varaždinske županije i okolnih krajeva, od kojih je građu o vilama prikazao u etnološkoj studiji Bajoslovje i crkva. Donosi i analitički prikaz Kukuljevićeve zbirke "Narodne pěsmw puka hrvatskoga" i pripadnog Predgovora u IV knjizi Različitih dela, kojem ona pridaje vrijednost programatske etnološke studije. Geografsku rasprostranjenost vjerovanja u monovrsne vile na istraživanom području potkrepljuje kartografskim prikazom područja vilinskih obitavališta. Zalaže se za revitalizaciju opjevanih narodnih običaja i usmene predaje o „bajoslovju“ radi obogaćivanja turističke ponude osebujnim kulturnim sadržajima uz zaštitu prirodnih i kulturnih spomenika vezanih uz takve predaje“. ${ }^{23}$

Drugi tekst pripada autoru Tomislavu Đuriću „Etnološko-folkloristički zapisi Ivana Kukuljevića Sakcinskog u «Danici Ilirskoj» (1842.-1846.)“, koji posebno naglašava:

„Ivan Kukuljević-Sakcinski, povjesničar, književnik i političar (1816. -1889.) u svojem svestranom radu posebno se bavio istraživanjima duhovne kulture hrvatskog narod. Stoga je izuzetan njegov doprinos hrvatskoj etnologiji i folkloristici. Dojmove sa svojih putovanja po hrvatskim krajevima opisao je u književnom listu „Danica Ilirska“ i u razdoblju od 1842. - 1846. godine. Objavio je velik broj članaka, pisama s vrijednim podacima o narodnom životu Hrvata polovinom 19. st. Ivan Kukuljević putuje i krajevima Austro-Ugarske monarhije i izvan državnopravnog prostora Hrvatske te tako opisuje naseljene Hrvate na prostoru između mađarskog grada Kisega i austrijske granice, koji se nazivaju „Vodeni Hrvati - „Wassercroaten“. Riječ je o Gradišćanskim Hrvatima (op. T. Đ.).

S puta po Dalmaciji Kukuljević zapisuje i malo poznate legende.

Za hrvatsku mitologiju posebno je vrijedan Kukuljevićev doprinos o vilama. Na osnovi istraživanja narodnog vjerovanja i pričanja o vilama od Dalmacije do Hrvatskog zagorja, Kukuljević je razvrstao tradiciju o vilama. On ih dijeli na zračne, zemne i vodene, a njih na dobre i zle na temelju dualističkog shvaćanja u narodu načela dobra i zla. Ove vile imaju pučka imena: „Vile oblakinje“, „Vile planinkinje“, ili "podgorkinje“ $\mathrm{i}$ „Vile vodene“. Vile koje žive u zraku, oblacima u pravilu su dobre, „Vile vodene“ su zlobne, „Vile planinkinje“ su prevrtljive. Hrvatsko narodoznanstvo (etnologija, smatra ovaj rad Kukuljevića kao prvu hrvatsku obuhvatnu folkloristiku studiju o vilama). ${ }^{24}$

Dubravka Franjković objavljuje svoj rad „O glazbi i glazbenicima u leksikografskom radu Ivana Kukuljevića Sakcinskog“. ${ }^{25}$ Vrsna poznavateljica Kukuljevićevih istraživanja na području glazbe zaključuje: „Djelo Ivana Kukuljevića Sakcinskog: „Slovnik umjetnika jugoslavenskih“ predstavlja korak dalje u razvoju hrvatske glazbene

\footnotetext{
Ibidem, str. 284.

24 Ibidem, str. 290-291.

25 Radovi, 16-17, 2006.
} 
kulture. ${ }^{26}$ Djelo se u Hrvatskoj javlja s neznatnim zakašnjenjem u odnosu na suvremene glazbeno-biografske leksikone drugih europskih naroda. Slovnik sadrži sistematiziranu, leksički obrađenu građu i rezultat je novog znanstvenog pristupa glazbi. Tim više što Kukuljević prilikom pisanja djela nije imao uzor u svojoj sredini“" ${ }^{27}$

Posljednji rad u časopisu Radovi pripada akad. Stjepanu Damjanoviću pod naslovom „Vatroslav Jagić o Ivanu Kukuljeviću Sakcinskom“. ${ }^{28}$ Autor se u svom radu pozabavio odnosom dvojice uglednih Varaždinaca. U zaključnih razmišljanjima zapisuje:

„Srpska kraljevska akademija objavila je dvosveščanu autobiografiju velikog hrvatskoga slavista Varaždinca Vatroslava Jagića pod naslovom Spomeni mojega života. U svojim sjećanjima Jagić spominje brojne osobe i osvrće se na njihove postupke i djela. Na 17 mjesta spominje i svojeg zemljaka Ivana Kukuljevića Sakcinskoga. Iz analize tih redaka i iz drugih izvora može se očitati iskreno i duboko međusobno poštovanje dvojice hrvatskih uglednika, ali i razlike u političkim nazorima i u pogledu na zadatke znanosti i njezine metode“ ${ }^{29}$

\section{Prema zaključnim razmišljanjima}

Bez obzira na relativno mali broj objavljenih tekstova autori, čije smo osnovne ideje naveli, u svojim su studijama o Ivanu Kukuljeviću Sakcinskom potvrdili nekoliko ključnih spoznaja:

Ivan Kukuljević Sakcinski bio je jedan od idejnih vođa hrvatskog narodnog preporoda, javni djelatnik, utemeljitelj ne samo brojnih znanstvenih disciplina već i brojnih ustanova arhiva, knjižnica, muzeja, časopisa, kulturno-povijesnih društava. Bio je sakupljač povijesne građe, povijesnih izvora, (zemaljski arhiv), izdavač značajnih povijesnih dokumenata, pisac znanstvenih povijesnih rasprava, biograf, arheolog, povjesničar umjetnosti, bibliograf i bibliofil. (Miroslav Kurelac).

Bio je osnivač, tajnik i predsjednik „Društva za povjestnicu jugoslavensku“, i prvog povijesnog znanstvenog časopisa „Arkiv za povjestnicu jugoslavensku“, bio

\footnotetext{
${ }^{26}$ To potvrđuje i Gorana Doliner kad piše: „Značenje Ivana Kukuljevića Sakcinskog u hrvatskoj glazbenoj kulturi i znanosti ostvaruje se na više razina: od podataka izučavanih na temelju Slovnika umjetnikah jugoslavenskih, preko priloga glazbenoj historiografiji, glazbenoj publicistici i glazbi, do priloga arhivistici pri čemu glagoljski izvori koji su vrijedni za proučavanje glagoljaškog pjevanja imaju svoje zasluženo mjesto." Gorana Dolinar, „Prinos Ivana Kukuljevića istraživanju glagoljaškog pjevanja“. U, Zbornik o Ivanu Kukuljeviću Sakcinskom, Zbornik radova s Međunarodnog znanstvenog skupa, Varaždin / Varaždinske Toplice 15.-17. travnja 2010., Zagreb, 2010., str. 468.

27 Radovi, 16-17, str. 159.

28 Radovi broj 25/2014.

29 Ibidem, str. 112.
} 
je načelnik i osnivatelj „Hrvatskog arkeologičkog društva“, podpredsjednik „Matice Ilirske“ i predsjednik „Matice hrvatske“, počasni član "Jugoslavenske akademije znanosti i umjetnosti“, te član mnogih uglednih znanstvenih udruženja i akademija. (Miroslav Kurelac).

Ivan Kukuljević Sakcinski jedna je od najznamenitijih javnih osoba u Hrvatskoj u 19. st., dok je kao osnivač moderne hrvatske historiografije temeljito obrađen u raspravi Jaroslava Šidaka. (Stjepan Hajduk).

Ivan Kukuljević je objavio temeljne zbirke izvora za hrvatsku povijest, a hrvatskoj historiografiji dao je i prvu organizacijsku podlogu. Svojom radinošću i plodnošću ostao je nenadmašan. (Stjepan Hajduk).

Kad je riječ o književnosti važno mjesto pripada Ivanu Kukuljeviću Sakcinskom koji je prvi i tiskom objavio opsežnu zbirku narodnih pjesama na sva tri hrvatska narječja. (Ivan Zvonar).

Tek je s Kukuljevićem počela znanstvena klasifikacija kajkavskih narodnih pjesama, tako da su danas njegove zasluge i na tom području nezaobilazne. (Ivan Zvonar).

Brojna Kukuljevićeva pisma suvremenicima, kao i njihovi odgovori Kukuljeviću, iscrpno nas izvješćuju o raznovrsnim djelatnostima svestranog kulturnog i političkog djelatnika. (Denis Peričić).

Ivan Kukuljević Sakcinski utemeljio je suvremenu hrvatsku biografiju, i kao njen teoretičar i kao pisac biografskih monografija i biografskih zbornika. Znanstvenim raspravama pridonio je razvoju biografske i povijesti hrvatske književnosti, a biografskim leksikonom utemeljio je i povijest umjetnosti. (Božena Filipan).

Za hrvatsku mitologiju posebno je vrijedan Kukuljevićevih doprinos o vilama. Na osnovi istraživanja narodnog vjerovanja i pričanja o vilama od Dalmacije do Hrvatskog zagorja, Kukuljević je razvrstao tradiciju o vilama. On ih dijeli na zračne, zemne i vodene, a njih na dobre i zle na temelju dualističkog shvaćanja u narodu načela dobra i zla. Ove vile imaju pučka imena: "Vile oblakinje“, "Vile planinkinje“, ili „podgorkinje“ i „Vile vodene“. Vile koje žive u zraku, oblacima u pravilu su dobre, „Vile vodene" su zlobne, „Vile planinkinje“ su prevrtliive. Etnologija, smatra ovaj rad Kukuljevića kao prvu hrvatsku obuhvatnu folkloristiku studiju o vilama. (Tomislav Đuričić).

Djelo Ivana Kukuljevića Sakcinskog: „Slovnik umjetnika jugoslavenskih" predstavlja korak dalje u razvoju hrvatske glazbene kulture. Djelo se u Hrvatskoj javlja $\mathrm{s}$ neznatnim zakašnjenjem $\mathrm{u}$ odnosu na suvremene glazbeno-biografske leksikone drugih europskih naroda. Slovnik sadrži sistematiziranu, leksički obrađenu građu i rezultat je novog znanstvenog pristupa glazbi. (Dubravka Franković).

Autori u svojim zaključcima inzistiraju na istraživanjima, ali posebno naglašavaju potrebu objavljivanja Kukuljevićeve ostavštine radi daljnjih proučavanja. 
Ovim tekstom želimo naglasiti još jednu važnu činjenicu, a odnosi se na sustavnije aktivnosti Zavoda za znanstveni rad Hrvatske akademije u Varaždinu. Naime, evidentna je razlika između broja sudionika znanstvenih skupova o Kukuljeviću (na manifestaciji „Kukuljevićevi dani“ u Varaždinskim Toplicama) i broja objavljenih radova. Postali smo svjesni potrebe da se u realizaciji skupova u isto vrijeme i tiskaju zbornici radova. Ta je praksa, naravno, uz redovito tiskanje časopisa Radovi, prihvaćena, i od 2000. godine Zavod je uvijek velike projekte realizirao kao znanstvenoistraživačke i nakladničke programe. Upravo je to omogućilo ne samo istraživanja, organizaciju skupova već i tiskanje zbornika. Tako su, da spomenemo samo neke, uz velike projekt tiskani i zbornici. Primjerice: Tržišna demokracija u Hrvatskoj - stanje i perspektive ${ }^{30}$, Stvaralački potencijali u funkciji društveno-ekonomskog i kulturnog razvoja sjeverozapadne Hrvatske ${ }^{31}$, 300 godina uršulinki ${ }^{32}$, Prometna povezanost Hrvatske s europskim zemljama u funkciji društveno-ekonomskog i kulturnog razvoja sjeverozapadne Hrvatske ${ }^{33}$, Adolf Jurinac i njegovo djelo ${ }^{34}$, Franjo Košćec i njegovo djelo ${ }^{35}, 800$ godina slobodnog kraljevskog grada Varaždina 1209. - 2009.36, Varaždin i sjeverozapadna Hrvatska u Velikom ratu 1914. - 1918. ${ }^{37}$

I opet se pokazalo koliko je važna nakladnička djelatnost. Vjerujemo, da je upravo ova konstatacija dovoljna da se izlaganja s ovog skupa tiskaju, sve u prilog veličini Ivana Kukuljevića Sakcinskog.

\section{LITERATURA}

1. Časopis Radovi Zavoda za znanstveni rad Hrvatske akademije znanosti i umjetnosti u Varaždinu.

2. Ljetopisi Hrvatske akademije znanosti i umjetnosti.

3. Zbornik o Ivanu Kukuljeviću Sakcinskom, Zbornik radova s međunarodnog znanstvenog skupa, Varaždin/Varaždinske Toplice 15.-17. travnja 2010., Zagreb, 2010.

4. Dokumentacija Zavoda za znanstveni rad Hrvatske akademije znanosti i umjetnosti u Varaždinu.

\footnotetext{
Varaždin, 2000.

Varaždin, 2002.

Varaždin, 2003.

Varaždin, 2005.

4 Varaždin, 2004.

35 Varaždin, 2008.

36 Varaždin, 2009.

37 Varaždin, 2014.
} 


\section{SAŽETAK}

\section{IVAN KUKULJEVIĆ SAKCINSKI U ČASOPISU RADOVI ZAVODA ZA ZNANSTVENI RAD HRVATSKE AKADEMIJE ZNANOSTI I UMJETNOSTI U VARAŽDINU}

U radu se prezentiraju istraživanja o Ivanu Kukuljeviću Sakcinskom koja su objavljena u ediciji Radovi Zavoda za znanstveni rad u Varaždinu. Riječ je, uz jednu iznimku, o autoriziranim izlaganjima na znanstvenim skupovima koji su organizirani na manifestaciji Kukuljevićevi dani u Varaždinskim Toplicama. Riječ je o slijedećim autorima: Miroslav Kurelac, Aleksandra Kolarić, Ivan Zvonar, Mirjana Matijević-Sokol, Stjepan Hranjec, Miroslav Šicel, Božena Filipan, Denis Peričić, Tomislav Đurić, Dubravka Franković i Stjepan Damjanović, koji je svoj rad prezentirao na skupu, Hommage Vatroslavu Jagiću 1838. - 2013. Okrugli stol održan u Varaždinu 23. rujna 2013.

Spomenuti autori u svojim su tekstovima naglasili najvažnije značajke života i rada Ivana Kukuljevića Sakcinskog.

Ivan Kukuljević Sakcinski utemeljitelj je ne samo brojnih znanstvenih disciplina već i brojnih ustanova arhiva, knjižnica, muzeja, časopisa, kulturno-povijesnih društava. Bio je sakupljač povijesne građe, povijesnih izvora, (zemaljski arhiv), izdavač značajnih povijesnih dokumenata, pisac znanstvenih povijesnih rasprava, biograf, arheolog, povjesničar umjetnosti, bibliograf i bibliofil.

Kukuljević je jedna je od najznamenitijih javnih osoba u Hrvatskoj u 19. st., a kao osnivač moderne hrvatske historiografije temeljito obrađen $\mathrm{u}$ raspravi Jaroslava Šidaka.

Kad je riječ o književnosti važno mjesto pripada Ivanu Kukuljeviću Sakcinskom koji je prvi i tiskom objavio opsežnu zbirku narodnih pjesama na sva tri hrvatska narječja. Tek je s Kukuljevićem počela znanstvena klasifikacija kajkavskih narodnih pjesama, tako da su danas njegove zasluge i na tom području nezaobilazne.

Kukuljević je utemeljio suvremenu hrvatsku biografiju. Kao njen teoretičar i kao pisac biografskih monografija i biografskih zbornika. Znanstvenim raspravama pridonio je razvoju biografske i povijesti hrvatske književnosti, a biografskim leksikonom utemeljio je i povijest umjetnosti. Također, za hrvatsku mitologiju posebno je vrijedan Kukuljevićevih doprinos o vilama.

Djelo Ivana Kukuljevića Sakcinskog: „Slovnik umjetnika jugoslavenskih“ predstavlja korak dalje u razvoju hrvatske glazbene kulture.

Svi su autori posebno naglašavali važnost objavljivanja Kukuljevićeve ostavštine, radi daljnjih istraživanja.

Ključne riječi: Ivan Kukuljević Sakcinski; časopis Radovi; Zavod Hrvatske akademije u Varaždinu; Kukuljevićevi dani u Varaždinskim Toplicama. 


\section{SUMMARY}

\section{IVAN KUKULJEVIĆ SAKCINSKI IN THE RADOVI ANNUAL OF THE INSTITUTE FOR SCIENTIFIC RESEARCH WORK OF THE CROATIAN ACADEMY OF SCIENCES AND ARTS IN VARAŽDIN}

The paper presents research on Ivan Kukuljević Sakcinski published in the Radovi edition by the Institute for Scientific Research Work in Varaždin. These are all, with one exception, authorized presentations from scientific conferences organised at Kukuljević's Days manifestation in Varaždinske Toplice. The authors are: Miroslav Kurelac, Aleksandra Kolarić, Ivan Zvonar, Mirjana Matijević-Sokol, Stjepan Hranjec, Miroslav Šicel, Božena Filipan, Denis Peričić, Tomislav Đurić, Dubravka Franković and Stjepan Damjanović, who presented his paper at the conference, Homage to Vatroslav Jagić 1838 - 2003. Roundtable held in Varaždin on 23 September 2013.

In their texts the aforementioned authors highlighted the most important events from life and work of Ivan Kukuljević Sakcinski.

Ivan Kukuljević Sakcinski was not only the founder of numerous scientific disciplines but also of many archives, libraries, museums, magazines, and of cultural and historical societies. He gathered historical materials and sources (state archive), published significant historical documents, wrote scientific historical discussions and was also a biographer, archaeologist, art historian, bibliographer and bibliophile.

Kukuljević was one of the most important public figures in Croatia in the $19^{\text {th }}$ century, and as the founder of the modern Croatian historiography, he was the subject in a thorough discussion by Jaroslav Šidak.

Ivan Kukuljević Sakcinski holds an important place in literature as he was the first to publish an extensive collection of folk tales in all three Croatian dialects. The scientific classification of Kajkavian folk songs did not start before Kukuljević so that his merits in this field are also of utmost importance.

Kukuljević founded the modern Croatian bibliography. He was its theoretician as well as the writer of biographical monographs and biographical collections of papers. Through scientific discussions he contributed to the development of biographies and the history of Croatian literature, and with the biographical lexicon he founded the history of art as well. Furthermore, his contributions on fairies are of exceptional importance for the Croatian mythology.

Ivan Kukuljević Sakcinski's work “Slovnik umjetnika jugoslavenskih" (Eng. Lexicon of SouthSlavic Artists) represents a step forward in the development of the Croatian musical culture.

All the authors stressed the importance of publishing Kukuljević's legacy for the purpose of further research.

Key Words: Ivan Kukuljević Sakcinski; Radovi annual; Institute of Croatian Academy in Varaždin; Kukuljević's Days in Varaždinske Toplice. ${ }^{38}$

\footnotetext{
38 Sažetak prevela Sanja Županić, prof.
} 